\title{
5 \\ History, memory and the politics of self-determination at an early outstation
}

\author{
Fred Myers ${ }^{\dagger}$
}

Looking back at the experience of the Pintupi outstation of Yayayi ${ }^{2}$ over the initial period 1973-75, when I was a PhD student doing field research there, I am divided between nostalgia and ambivalence. One can hardly ignore the memory of Pintupi people's excitement to be away from the tensions and density of the large government settlement of Papunya, or the distinctive embrace of the resurgent civil rights movement expressed at Yayayi in a language of 'Black Power'. Yayayi was one of the very first 'outstation communities' in the Northern Territory under the umbrella of changes articulated by the Whitlam Government's embrace of

\footnotetext{
1 This research was supported by a research grant from the Australian Institute of Aboriginal and Torres Strait Islander Studies (G09/7478) and an Australian Research Council (ARC) Linkage Grant, 'Pintupi Dialogues: Reconstructing Memories of Art, Land and Community through the Visual Record' (2010-13). I want to thank my collaborators on the project, Pip Deveson, Peter Thorley, Ian Dunlop and Nic Peterson, for their help and insight. I would like to acknowledge the contribution of our Pintupi consultants on this project: Irene Nangala, Monica Robinson Nangala, Bobby West Tjupurrula, Jimmy Brown Tjampitjinpa and Marlene Spencer Nampitjinpa.

2 There have been many spellings in the literature to refer to this place, depending on how non-Indigenous speakers heard the name, and we have included them as they occurred in archival materials. The spelling of 'Yayayi' represents the orthography and phonology currently used in literacy materials.
} 
something we call 'Aboriginal self-determination'. A powerful notion at the time, as Peter Sutton (2009) has testified, this phrase needs to be kept in quotation marks, as we should, I suggest, explore what this political slogan meant.

The exuberance of Pintupi returning to Yayayi, $40 \mathrm{~km}$ west of Papunya, was palpable. Their enthusiasm was matched by indeterminate expectations, by inchoate ideas of a future. Nonetheless, for me to have been there, as a young man with an equally un-nuanced progressive view of a possible future, is the source of my nostalgia, which, I suspect, is shared by many who lived or worked on the early outstations.

Let me consider for a moment, then, what I mean by 'ambivalence'. What did Yayayi amount to? I want to think about this because in recent years, the political screw has turned and one routinely now hears that the project or policy of 'Aboriginal self-determination' was a failure, the source of a perceived current severe dysfunction in many remote communities (see, for example, Hughes 2007; Johns 2001; Howson 2000). Many of us who did research in remote communities in the 1970s were strong supporters of an Aboriginal right to self-determination, as Peter Sutton has (again) pointed out, and in that sense, we may feel implicated in these results. What went wrong? It is important to say here that these policies were not really the consequence of the sympathies of anthropologists. The movement for Aboriginal self-determination was embedded in and catalysed by international movements of national liberation, civil rights and human rights.

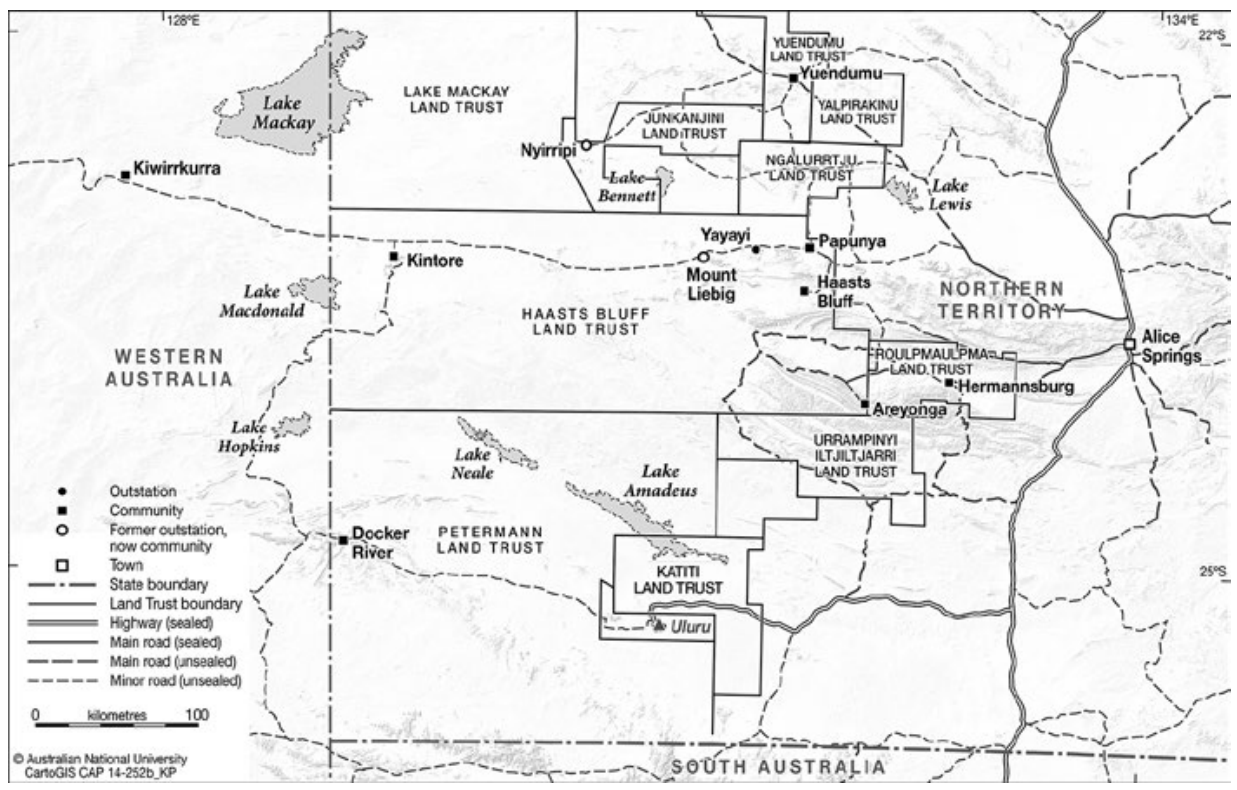

Map 5.1 Yayayi in relation to Papunya and Kintore.

Source: Karina Pelling, CartoGIS, ANU College of Asia and the Pacific 
In my initial imaginings of this essay, I was expecting to go back to the experiences of everyday life at Yayayi, through my notes, government documents and the film footage that Ian Dunlop shot there in $1974 .^{3}$ To explain briefly, Dunlop came to Yayayi in 1974 to follow up with Pintupi people he had met with Jeremy Long on one of the last 'Pintupi patrols', at a time when people were leaving their homelands for Papunya and other government settlements. Dunlop was thinking of making a film that would explore what had happened to people who had so much impressed him. He shot 12 hours of $16 \mathrm{~mm}$ colour sound-synchronised footage, but he never made it into a film. In 1975, with the help of two Pintupi consultants, I translated and further documented the footage. Thirty-two years later, after it had been deposited in the National Film and Sound Archive and been transferred to tape and then digitised, I took the footage back to the Pintupi communities of Kiwirrkura and Kintore as part of a project of repatriation. Based on the enthusiastic reception of the footage in those communities, this footage and Pintupi responses to it have provided the instigation for the project of which this essay is a part - namely, a re-examination of the early moment of self-determination in a remote outstation.

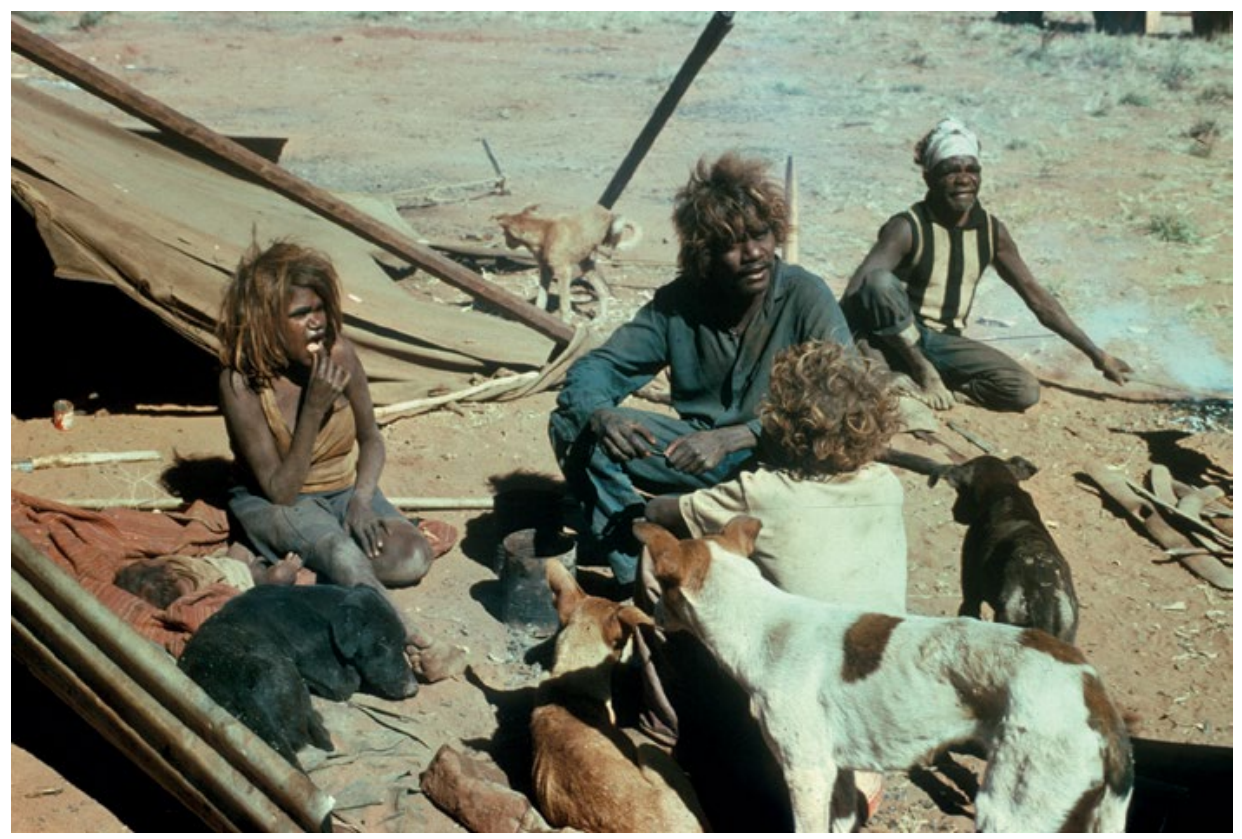

Figure 5.1 Minyina Tjampitjinpa's camp at Yayayi, 1974.

Source: Fred Myers

3 My original monograph based on this fieldwork, and later research, was published in 1986 (see Myers 1986). 


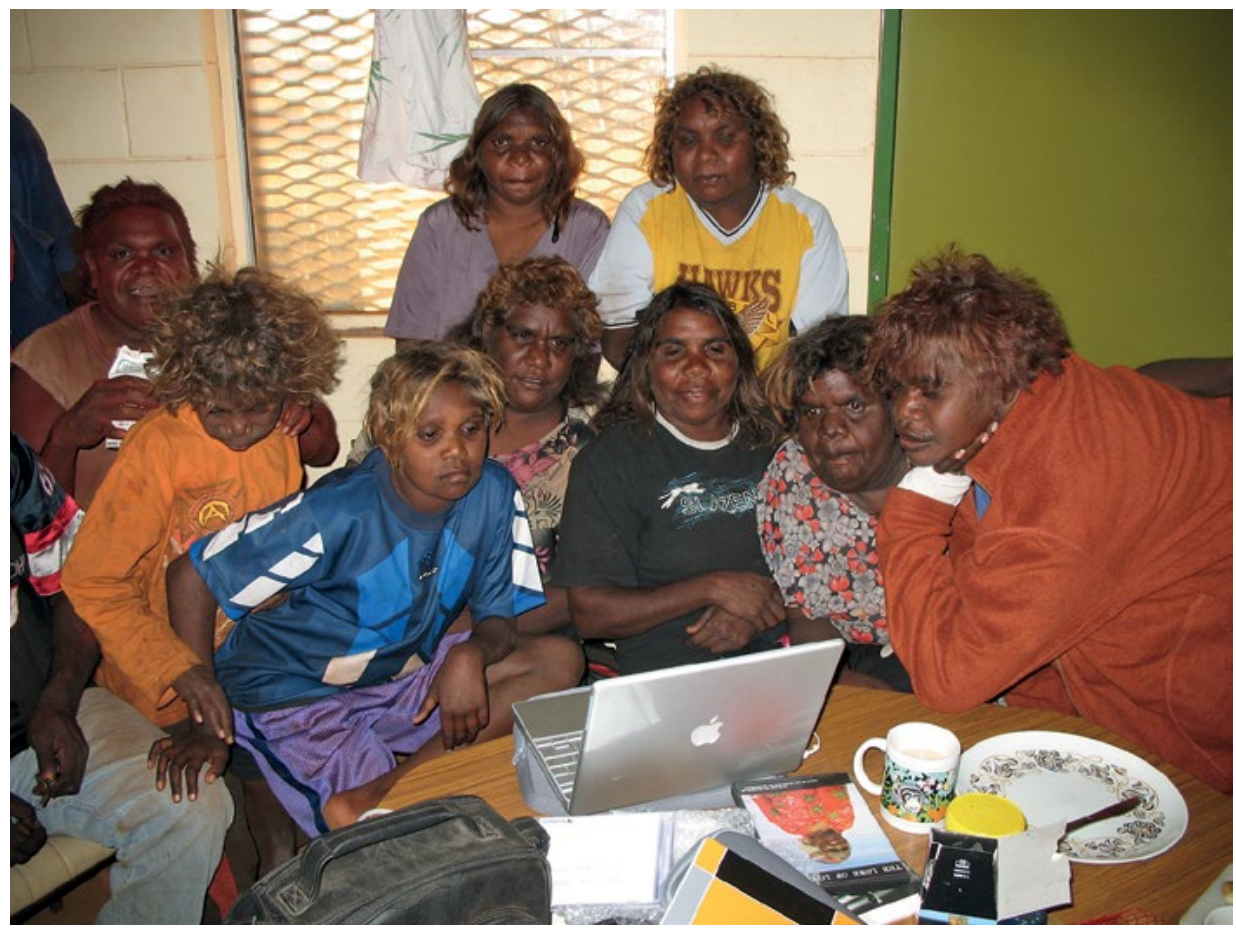

Figure 5.2 Pintupi watching archival footage, Kintore, 2006.

Source: Fred Myers

In asking 'What was Yayayi? What did it amount to?', I have come to realise that how it looks varies according to different subjects, with a range of social imaginaries. In the research undertaken with the Yayayi film footage, Pip Deveson, Peter Thorley and I interviewed a range of people involved in Yayayi - including most of the non-Indigenous participants who were there and five Pintupi consultants who had lived, as young people, at the outstation. Our research sought to understand what Pintupi people found interesting or important in the film material and, relatedly, what the experience or memory of Yayayi - as well as of self-determination - might be.

The most immediate responses to seeing the old footage, as I learned from a nursing sister who was living at Kiwirrkura in 2006, concerned the apparent 'health' of the folks living at Yayayi. 'We were so healthy then', many of the Pintupi viewers remarked, according to this report. In contrast, certainly, to the more common obesity of the present, the fitter bodies of the men and women in 1974 were quite noticeable and meaningfully so in the context of the severe challenges to health of the present, with high rates of renal failure and diabetes.

Let me explain why one might regard these comments with some ambivalence, perhaps even 'irony'. 
Despite the celebration of the outstation movement in many accounts of the early 1970s, its inauguration at Yayayi was considerably more fraught. The movement of Pintupi to Yayayi was part of a series of attempts to allow Pintupi to separate themselves from the larger complex of Papunya. Jeremy Long, who has an essay in this volume, had proposed such decentralisation westward as early as 1962 . As the latest (even last) people to migrate from the Western Desert, many Pintupi arrived at Papunya in the 1960s under the somewhat negative characterisation of 'myalls'; they were seen as ignorant and less civilised by their more knowledgeable brethren who had experienced contact earlier. Additionally, the movement in from the bush exposed them to disease and infection that resulted in a substantial series of deaths - a rate of dying some officials suggested was compounded by a lack of will to live in the new circumstances. When they first went to Papunya (in 1966), the linguist Lesley Hansen remarked in one of our interviews, 'You'd hear crying and we'd say, "Why are they crying?" And they'd say, "All the Pintupi are going to die. They're going to finish up"' (interview with Lesley Hansen, 2011). The mounting death toll and illness seemed overwhelming. These are among the specificities of the Pintupi history as it relates to self-determination and to outstations.

\section{The desire to live independently}

These circumstances were a worry, indeed a problem, for the Welfare Branch of the NT Administration and later the Department of Aboriginal Affairs - fearing the bad publicity but also out of genuine concern. To alleviate the problemsillness, morbidity, conflict and depression - an initial outstation was founded at a bore away from Papunya called Waruwiya, where Pintupi moved in 1967. When this water source was found to be a health problem, with high levels of nitrates, it had to be abandoned and the Pintupi returned to Papunya. In 1970, another outstation community was established, at Alumbara Bore, about $30 \mathrm{~km}$ west of Papunya. Life here was, apparently, very satisfactory for the Pintupi who moved there, but a conflict with police and the difficulties of administering this location again forced the Pintupi back. During this time, various officials of the regional Welfare Branch (and later Department of Aboriginal Affairs, DAA) continued to look for locations to allow the Pintupi to hive off from the larger settlement. At the time, movement back into their own traditional countrymuch further west near the NT border - was considered impossible: there were no bores out there and the difficulties of servicing such a remote location were regarded as insurmountable. 
Nonetheless, the accounts suggest that Pintupi leaders continued to agitate for the establishment of a separate community, and this became possible in early 1973. Indeed, as soon as the location of Yayayi — at a place also called Kakali Bore-in Luritja territory ${ }^{4}$ became possible, they moved out with some support from the DAA.

T. C. (Creed) Lovegrove's ${ }^{5}$ account of the situation to the next Minister of Aboriginal Affairs, James Cavanagh, written in January 1974, is clear:

When the group moved to Yai Yaia on 4th June 1973 it was a decision that the Pintubi group itself made because they were fed up with being discouraged from moving because of administrative difficulties. The departmental representatives at Papunya assisted them with transport, but it would have been more convenient to the Departments of Aboriginal Affairs Health and Education if the group had not insisted on moving at that stage as none of these departments were geared to provide a satisfactory service to the community. However, the Department of Aboriginal Affairs recognized a right of self-determination in this decision of the community. [Emphasis added] ${ }^{6}$

It was the end of what those who still remember call 'Welfare Time'. In an interview I had with Marlene Spencer Nampitjinpa (in June 2013), a Pintupi woman who was a teenager in 1974, Marlene delineated the period as one of governmental supervision: of settlement officials coming to camps to make sure children went to school, for example, or even showing them how to take showers. These were hallmarks of an earlier policy of paternalism or training, in which the government settlements had kitchens providing food for residents, especially older people and children. 'Welfare time,' she remarked in remembering school, 'not allowed to stay in camp'. Others remember a time of dependency on white institutions 'like the kitchen coming in, three meals a day. They were just sitting there, waiting for the next meal. It was very debilitating' (Ken Hansen, interview, 2012). These are the circumstances about which C. D. Rowley (1971b) wrote so devastatingly against 'total social institutions'.

The government support of local aspirations to move out of large, mixed settlements sounds like a good story. Consider the following statement by the Minister for Aboriginal Affairs, Gordon Bryant, offered shortly after the Pintupi move:

The Federal Government has made an urgent grant to a group of 250 Pintubi Aborigines in the Northern Territory to help them establish their own community.

\footnotetext{
4 The 'Luritja people' here refers to the speakers of a different dialect of the general Western Desert language, who lived to the east of those known as Pintupi. See Tindale (1974).

5 Lovegrove was a senior official of the Department of Aboriginal Affairs, based in the Northern Territory.

6 National Archives of Australia [hereinafter NAA], Canberra: F1, 1973/6202 Pintupi Outstation Yai Yaia, p. 29, Letter of 17 January 1974.
} 
The Minister for Aboriginal Affairs, Mr. Gordon Bryant, announced today that he had approved a grant of $\$ 30,000$ to cover the cost of items requested by the group.

The Pintubi group had decided earlier this month to move from Papunya, where they had been living with other tribes, to their new site at Yai Yaia, 24 miles [19 km] away.

The only facility at the new site was a stock water bore ...

'Their move is an expression of their desire to live independently,' he said. [Emphasis added $]^{7}$

\section{The controversial move: Political ironies of self-determination}

Apparently, this movement did not enjoy universal support. For reasons I cannot trace effectively, this Pintupi outstation move came under substantial criticismfrom unlikely sources, indeed, from those with a deep concern for Aboriginal wellbeing. The well-known advocate for Aboriginal health Dr Archie Kalokerinos is featured in a segment of the Australian Broadcasting Corporation (ABC) program This Day Tonight aired on 26 June 1973. Along with the then young Indigenous political activist Neville Perkins (nephew of Charlie), Kalokerinos appears in this segment and expresses his deep concern about the health situation of Papunya and, secondarily, of Yayayi. In what I find to be a very disturbing scene, Kalokerinos asks the Pintupi medical aide, Pinny Tjapaltjarri, to demonstrate how he gives eyedrops. Talking to the camera as if Pinny Tjapaltjarri-a Ngangkari trained by the health service as part of an attempt to give responsibility to local people - is either not present or incapable of understanding, Kalokerinos is critical of Pinny's knowledge. After the narrator explains that Pinny had only an hour's training in preparation to become 'the guardian of health' for the community, Kalokerinos watches Pinny use an eyedropper and comments: 'It's quite obvious that in Benny's [Pinny] untrained hands, infection is really spread from one eye to another.' Such comments suggest to the viewer that the health situation at Yayayi is unmanageable without white presence-although the Pintupi themselves were determined to be there. The implication of the broadcast, therefore, subsequently articulated in a letter sent to the Minister of Aboriginal Affairs by a viewer, is that the movement to the outstation was a government project taken without consideration of Aboriginal well-being. If, in the end, this challenge helped persuade the Health Department to agree to send 
a nursing sister on a regular basis, it also threatened the entire Pintupi project and imposed a Euro-Australian set of values and judgments against those of the community.

Subsequent to the broadcast, Bryant reiterated the Labor Government's policy in a response to a disturbing letter from a citizen of Adelaide who had seen the segment. Aileen Thompson had written a letter to The Advertiser. ${ }^{8}$ In reply, Bryant wrote:

First of all, let me assure you that it is in the intention of the present government to do everything that is possible to improve the quality of life of this group of people, but we will be governed to a large extent by the expressed wishes of the people themselves and will not impress upon them those values through which we as Europeans judge to be important to a quality of life.

You will probably be interested to know that this group of Pintubi Aboriginal came to Papunya several years ago and have in the last few years been anxious to establish their own community. The decision that brought about their move from Papunya to Yai Yaia was one that they made entirely on their own and since moving the morale of the group has lifted considerably ...

An officer of my Department is working in close liaison with the community and they are expressing great interest and initiative as a result of the opportunity which is being given to them to become more closely involved in their own future welfare and a responsibility for decision making on their own behalf.

Much has to be done to assist these people and other Aboriginals in Australia, and you can be assured that while the present Government is in power we will be working towards this end but will continue to have as our guiding principle the self-determination of Aboriginal communities themselves. ${ }^{9}$

There was also a furious exchange of telegrams between the DAA officials and Neville Perkins about Perkins' claim that it was his personal intervention that resulted in the grant of vehicles and other resources to Yayayi. ${ }^{10}$ The DAA had put these requests into play before his arrival, they insisted; they sought to deny the implication that they had failed to help these people appropriately. I relate these tensions to indicate the complex field of responsibilities and goals invested in the outstation. If one extends the interpretation of Kalokerinos's intervention, and

8 The letter in The Advertiser [Adelaide] was published on 5 July 1973. See NAA: F133, 1968/60 Papunya Outstation, p. 11. She also wrote a letter directly to Bryant. NAA: F1, 1973/6202 Pintupi Outstation Yai Yaia, p. 128, Letter 10 July 1973.

9 NAA: Gordon Bryant, 9 August 1973, F1, 1973/6202 Pintupi Outstation Yai Yaia, p. 105.

10 NAA: Folder 53883095, Pintupi Outstation Yai Yaia. Indeed, R. McHenry, the senior DAA officer in Darwin, wrote in response to this claim: 'Initial \$30,000 grant based on reports of Owens following consultation with Pintubi people. The visit by your group and particularly those comments offered by Mr. Bruno helpful in confirming assessment of initial needs. I will not have it inferred that anyone other than the department and its agent Owens which commenced a special study on this matter two months ago was responsible for the grant.' NAA: F1, 1973/6202 Pintupi Outstation Yai Yaia, p.144. 
that of Perkins, one can see the outlines of a continued paternalism (concern for Aboriginal health defined in Western terms) arrayed against local Indigenous desires to move to outstations - their version of 'self-determination'.

I do not offer this history in order to take a side in this contest, the stakes of which seem to resemble the concerns that Peter Sutton $(2001,2009)$ defined for himself some years ago about what ethical responsibilities one might have in regards to people's well-being. I have pursued this account because it highlights, very exactly, the ironies of 'self-determination' at Yayayi, with those who ordinarily advocated Aboriginal self-determination impeding a determined Indigenous decision and seemingly doing so in terms of a Western health rationality.

I have to put my own cards on the table. I identified with and supported the Pintupi desire to determine their own trajectories and values. I do not believe it could have been different. The privilege of doing research at Yayayi during this emergent administrative period of self-determination required local permission. The Pintupi at Yayayi said they were happy for me to be there, but they made it clear that I was expected 'to help Aboriginal people'. One could hardly, in those circumstances, strongly question or challenge their decisions or judgments. To do so was seen as a return to the pattern of the previous welfare regime - a pattern they rejected in claiming what they took to be their rights to self-determination. This commitment - and commitment it was - was nonetheless sometimes in tension with my subjective experience and also my cultural position as a Western person. For example, motor vehicles were an endless problem at Yayayi (see Myers 1988), as I have described elsewhere. According to the dictates of Aboriginal self-determination, the vehicles (trucks) granted to Yayayi from the DAA (and elsewhere) - its most valuable capital items - were provided to serve the community for work and for getting food stores from Papunya. Not surprisingly, these vehicles were frequently taken on hunting trips and taken off road, with rather bad mechanical outcomes (ranging from broken axles and stripped transmission to total wreckage). If the mobility and opportunity to get out into the country were a huge boost to morale, there was also very clearly a conflict between Indigenous values (the vehicle in the service of relatedness, kinship obligations, hunting as a valued activity and mobility) and Euro-Australian values (use only for assigned purposes, accountability to grant provisions, contracts, and so on). Moreover, the local leaders in charge of the vehicles could hardly refuse the requests of their relatives to help them, lest they forfeit their authority under the requirement to help. 


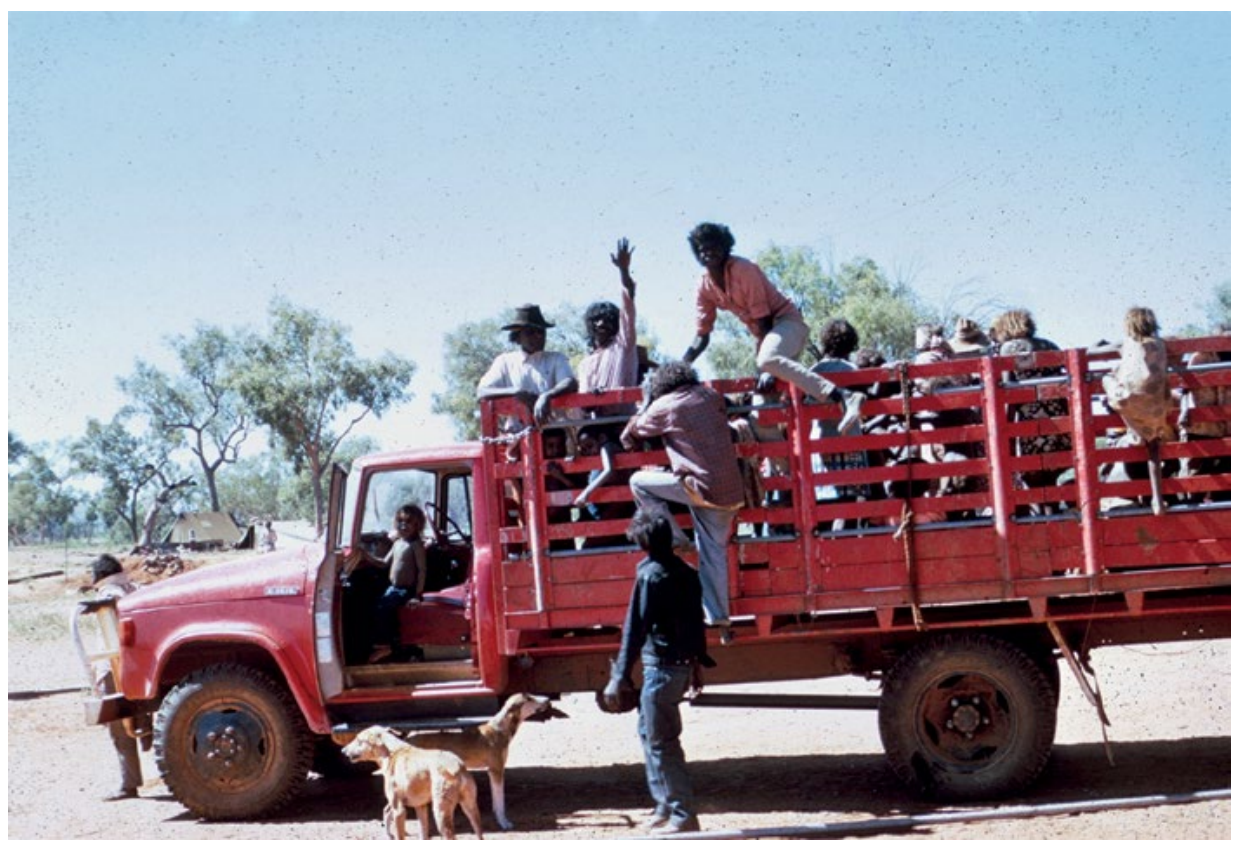

Figure 5.3 All aboard the 'red truck' at Yayayi, 1973.

Source: Fred Myers

One must remember, this was a particular political moment - in Australia and the world. At Yayayi, although teenagers wore denim jackets decorated with the words 'Make Love, Not War', the talk was of 'Black Power'. 'Black Power', as it was articulated, was not nuanced, but it was largely understood as a change in the relationships of whites and blacks. Rumours about the content of 'self-determination' abounded: some thought all the resources and assets of Papunya were to be turned over to the Aboriginal people. The reach of 'Aboriginal self-determination' was not itself evident. Restrictions on their 'autonomy', to use a word that I have clarified elsewhere (Myers 1986), were difficult to reconcile with what they were told in countless meetings with Euro-Australians (officials as well as political activists) about 'self-determination'.

\section{Black and white}

The field of Indigenous/Euro-Australian relations at Yayayi and Papunya was quite unstable - as I learned very quickly. After getting permission to conduct research at Yayayi in July 1973, I still had to return to Alice Springs and get the equipment for a long stay. Within a few days of returning to Papunya, passing through the so-called 'European' area that was spatially segregated, 
with the 'Europeans' ${ }^{11}$ living in more substantial houses and the Aboriginal people in transitional houses or tents, I wrote in my journal about hearing the white workers - 'old hands' (former Welfare Branch employees, now part of the DAA) who did seem to 'like' Aborigines and to care about them-discuss what they referred to as the 'half-caste problem'. They questioned Gordon Bryant's new administration of the DAA and the 'new-made Aboriginal experts' of the emerging era. In a time of transition in Aboriginal affairs, marked by the change in title and administrative location from the Welfare Branch to the DAA, the local public servants were not entirely happy; their remarks made it clear that they intended me to be addressed as a 'European'. They expressed their concern with the way money was 'thrown around' and the change towards a policy of 'Aboriginal self-determination' that meant superintendents could only give advice. 'The Yayayi council truck is used like a taxi', my field notes record one Papunya administrator as telling me in a critical tone. For these men, settlement life was spinning out of control.

There were hints that the situation at Yayayi was tense when I got there. Paul Bruno, an English-speaking Pintupi boy whom I met on my first drive to Yayayi, made a point of informing me on that very day that Neville Perkins, then known as a radical Aboriginal activist, had been at Yayayi and that he had struck a memorable chord. 'Laurie Owens doesn't help the Pintupi,' Paul told me, 'but Neville does.' ${ }^{12}$ Neville had arrived with news of a truck delivered from a government grant, which local people saw as his doing; by other accounts, he was delivering one supplied by DAA. This was the occasion for the furious exchange of telegrams and accusations. Laurie Owens was the DAA officer who had become the community adviser for the Yayayi community, and he was known to be hugely supportive of this move for independence. Neville and Laurie had an argument, Paul told me. He reiterated that Laurie 'doesn't do anything for the Pintupi, but Neville does' ${ }^{13}$ The idiom of 'helping', of course, was a crucial moral discourse, as vital in Pintupi cultural understandings as it was for activist criticism. The 'old men' (that is, the authoritative senior figures), according to Paul, were thinking of kicking Laurie out and putting Neville in as community adviser. I realised something political was going on, and I could see a reorganisation of alliances - with Perkins' shared Aboriginal

\footnotetext{
11 The category 'European' was used particularly by whites to refer to themselves, as distinct from 'Aboriginal' people, and in that sense it's primary referent was white Australians. The local Aboriginal English referred to 'walypalas', as distinct from 'blakpalas' and (sometimes) 'yellafellas' or 'half-castes'.

12 Neville Perkins, nephew of the well-known Aboriginal activist and leader Charles Perkins, had family origins in the Alice Springs area, but had grown up 'down south' and was a student at the University of Sydney. 13 Telegrams in the archive show how heated their encounter must have been. Perkins wrote to Laurie Owens, shortly after the visit: 'In discussion with [R. W.] McHenry Darwin Tuesday Shorty Bruno, Helmut Pareroultja and I secured a $\$ 30,000$ immediate grant but the issue of your role and credibility is still at stake. Representations will be made to Bryant. It would be foolish to intimidate [sic] anyone else.' NAA: F1, 1973/6202 Pintupi Outstation Yai Yaia, p. 145.
} 
identity challenging Pintupi confidence in Owens, the significance of his local knowledge and the good faith of the DAA. ${ }^{14}$ Settlement workers' jarring (to me) characterisation of Neville Perkins as 'half-caste', implying for them a lesser Aboriginality, and as an interloper (lacking real knowledge) traced this anxiety. I felt very uncomfortable myself, a possible target of activist anger as a white interloper and also someone who had received some help from the actual target of Perkins' accusations.

My concern was probably not unwarranted in those days - for example, Perkins had even threatened to have the popular Summer Institute of Linguistics (SIL) linguist Ken Hansen sent away! While Hansen's regard for the Pintupi should have been beyond question because of his long dedication to their concerns (as clearly indicated in the various reports I have seen in the National Archives of Australia files), ${ }^{15}$ Perkins was suspicious of him and questioned whether Hansen was accurately translating what Pintupi leaders said about their desires to live at Yayayi. ${ }^{16}$ It says something about the confusion of the time, and the uncertainties of race politics, that some Pintupi may have doubted Hansen's commitments.

Beyond these intricate complexities, people spoke enthusiastically that there was a 'new government', and now whites must 'help' Aborigines. For the Pintupi who were living at Yayayi when I arrived in 1973, such ideas no doubt informed the view that I should 'help Aborigines'. This concept elided easily as well with the understanding of me as becoming a 'one-countryman', so that the politics of self-determination made sense in the culture of Pintupi politics (see Myers 2006). Nonetheless, I understood this obligation as a serious practical condition, and an ethical one that I accepted, as someone who came of age on the politicised North American campuses of the 1960s.

There was a lot going on here, especially concerning the shifting frameworks to define relationships between various kinds of people. Here I want to note especially the framework of Aboriginal power, desperately sought, but also the contradictions: while strong supporters of Aboriginal power such as Kalokarinos

14 Another level of complexity or conflicting interests, depending on one's point of view, is that Owens seems to have had considerable support from and connection to very senior people leading the self-determination policy, such as Barry Dexter in Canberra. Dexter wrote to R. W. McHenry, the senior DAA officer in Darwin, copying to him what he wrote to Owens: 'We at head office are pleased that there has been quick response to Pintubi group's decision to move to Yaiyaia. We understand their anxiety to move from Papunya without further delay ... We consider any attempt to delay or hinder free movement of the group as a whole or individuals would be indefensible. This applies equally if as result of boring program in reserve groups later wish to move to places farther west.' NAA: F1, 1973/6202 Pintupi Outstation Yai Yaia, p. 132, 25 June 1973.

15 NAA: F1, 1973/6202 Pintupi Outstation Yai Yaia, pp. 73-4.

16 Owens writes in a report about the discussions at Yayayi, on 7 June 1973, 'I was somewhat surprised to be informed by Mr. Perkins that last night he had rethought things after discussion with Sister Livingstone and that he felt that Mr. Hansen had not competently interpreted for him and that he had not conveyed the point of the questions he had asked.' NAA: F1, 1973/6202 Pintupi Outstation Yai Yaia, p. 160. 
and Perkins were, at least initially, opposing the Pintupi initiative to move out of Papunya, to seek their own autonomy and community, the DAA, ostensible object of their criticism and certainly not lacking some doubters, was supporting the local Aboriginal decisions and refusing to impress on this community the values through which Europeans might judge the quality of life. ${ }^{17}$ At the same time, the various government agencies were in disagreement. Owens' response as a DAA officer to the Pintupi impatience about moving was resisted by the head nursing sister at Papunya, who, representing the Department of Health, felt that arrangements for health and also for visiting nurses' safety were inadequate. It was this nursing sister, partly representing her view of the potential health challenges for small children against the wishes and desires of their kin, who apparently drew Perkins and Kalokerinos into the drama.

\section{From black and white to colour}

I now turn to the theme of a 'healthy' Yayayi provoked by the Pintupi engagement with the archival footage. The attribution of 'health' or 'well-being' has been a comment from nearly every Pintupi viewer. How does it look from the outside? As I have now had the opportunity to screen the footage to others unfamiliar with Yayayi or even Aboriginal realities as many of us have come to know them, the claim of 'healthy people' does not square with what they see.

Some American viewers see dogs licking at meat being butchered, for example, just as Kalokerinos saw the eye infections and dangers of diarrhoea. They see a food supply, discussed by one of our consultants, Marlene Spencer Nampitjinpa, that is not really 'healthy': white bread, self-raising flour, cold drinks, sugar and tea. Indeed, in our interview with Marlene Nampitjinpa, my fellow filmmaker Pip Deveson honed in on exactly this issue, asking Marlene if she thought the food they ate at the time was good food. Marlene found this question confounding. Although she has been a leader in the Pintupi Homeland Health Service and an advocate of a healthy lifestyle, my impression is that knowledge about nutrition is not informing her evaluation of what she sees and what she thinks about the past at Yayayi. For her, health is something broader.

The health theme is illustrative of a general orientation to the Yayayi experience and to the film record. Pintupi consultants emphasised four significant themes in what they saw. These themes were: health, sharing, family and people being

17 Indeed, Owens expressed precisely this view to the director of the DAA in Darwin: 'He [Perkins] feels that responsibility is being placed too quickly on the Pintubis and he said that he was concerned that the pace for change was too great. I feel that this is a contradiction when in fact he wanted facilities to be placed at Yai Yaia before any movement took place. I think that needs have been adequately expressed and time scales appropriately expressed also. To me it seems that Mr. Perkins is still very paternalistic - a thing I thought he was against.' NAA: F1, 1973/6202 Pintupi Outstation Yai Yaia, p. 159, Letter from Laurie Owens. 
happy, and the strength and commitment of the leaders, elders. These themes recurred in all of the commentaries of our consultants, but are equally evident in the meetings that were filmed at Yayayi in 1974.

It seems as if the major arenas of 'self-determination' at Yayayi in 1973-75 were 'health' (with a local Ngangkari as the health worker), 'language' (with bilingual education and the development of materials in Pintupi), the local Aboriginal 'council', and the increased ability to hunt and gather food for themselves through access to 'vehicles'. The themes offered by the Pintupi consultants are all very positive, supporting a view of this period as a happy one, a healthier one, with people speaking for their community. As a corollary, indeed, my friend and our consultant Bobby West Tjupurrula, in particular, emphasised himself as taking a lead from these older people in becoming a leader and speaking for his community. Monica and Irene, similarly, saw a commitment to looking after the community that they regard as lacking in the present (and probably especially so with the creation of the shires that have evacuated local governance). In viewing the film footage from 1974, Marlene commented on how these older people 'worked for us'. She also identified herself as continuing this commitment, as a health worker and leader: 'I try to help my people' (Marlene, interview, Alice Springs, June 2013).

Most of the non-Indigenous interviews we have undertaken in relation to the archival footage have had a decidedly different cast, viewing the outstation more as a dysfunctional failure. I have to say some of these opinions surprised me. But I would cite Ian Dunlop and also Terry Parry, ${ }^{18}$ the schoolteacher at Yayayi, as sharing a disappointment in what they saw and experienced. I believe Ian was disturbed by the violence he observed, especially during a particularly extended period of alcohol consumption while he was there. Both Parry and Dunlop had things stolen from their camps or caravans - events that turn up in the film footage. In Parry's case, what were stolen were the headphones he used as a schoolteacher for the hard-of-hearing children, as well as his own property. His disappointment was surely exacerbated by the fact that the destruction had its effect on other members of the community itself - a rather sad statement about Pintupi community spirit or concern for others. Dunlop felt that the theft was so out of tune with his experience in other Aboriginal communities and in Papua New Guinea-where no one, he maintained, had ever taken anything - that it was a sign of moral decay. He did not recognise in Yayayi the people he had met on patrol with Jeremy Long ten years earlier. Yayayi, for him, seemed fundamentally and sadly different from Pintupi life in the bush. Finally, both men were also disappointed at the inability of the community council to address this problem. 
In contrast, the Pintupi consultants spoke with great respect for what they saw in the meetings held by the men of the community, with what they saw as 'speaking strong' and as actually demonstrating concern. They found this to be a striking difference from the present (of 2009-12), where there is insufficient concern and taking of responsibility for communal well-being.

These perceptions raise the question, in fact, of what Yayayi was. I have used the word 'community', which was more or less how it was understood by the DAA and others. The people living at Yayayi were still subjects of the Australian state, and the Northern Territory, but no longer wards, as they might have been some years before. The formal organisation or leadership of Yayayi was established through an elected council that administered (signed, and so on) the budget and resources that belonged to the incorporated council, but - as I have written elsewhere - was not really recognised by other Pintupi to have the authority to punish wrongdoing or to legislate rules. ${ }^{19}$ The council members, who were supposed to represent the voice of the 'community' of which they were the leaders, tried to break up fights and they went to meetings with government officials and others on matters of community business. They were 'bosses' of a sort, but they were expected to 'look after' the community, to help them. And if they refused the material requested, this was typically viewed as a failure of care. They were, nonetheless, the agents in whom 'self-determination' was located.

In retrospect, perhaps too much was expected of the council, and also of the community's capacity for self-determination. They exercised this strongly in many ways, however, and often successfully, in their view. To me, the most successful exercise of their rights lay in their insistence that no one could visit without their permission (they had to be asked) and no one should/ could be permitted to travel to Pintupi country without asking. 'That's our country', councillors would say, 'not just anyone's. Not allowed to travel there without asking.'

Others spoke with muted anger about the appropriation of their stories and the theft of sacred objects (Jeremy Long, in one of his reports in the 1960s, noted the concern about listing Tjitururrnga as a sacred site, with significant objects, and the decision not to make note of its location in order to prevent looting or desecration). And, as a consequence of filming trips made to record ceremonies in their own country, they were attempting to work out a framework in which their custodianship responsibilities and privileges were acknowledged and respected by outsiders. ${ }^{20}$ This was part and parcel of 'Aboriginal self-determination' in which Yarnangu (Aboriginal people) would

19 For discussion of Pintupi ideas about local politics and authority, see Myers (1985, 1986).

20 An account of the changing attitudes towards and the projects of salvage filming of Pintupi (and Warlpiri) rituals can be found in Ian Bryson (2002). 
be able to decide, even to refuse or reject, the requests of white people-refusals that were sometimes accompanied by such a notable anxiety that one could reckon the reversal it reflected: Black Power.

If they felt that their authority was being disregarded, local leaders - or even other Pintupi in the community-might evoke the threat of going to the institutions that they thought defended their rights: Aboriginal Legal Aid, in those days, or even Neville Perkins. How often did I hear that Neville would send these interlopers packing! If a mechanic would not fix your car, one heard, Legal Aid would get rid of him. Of course, in those early days, the extent of these powers was sometimes imagined excessively, indicating the uncertainty of it all and, to some old hands no doubt, a still humorous lack of 'real' knowledge.

At Yayayi, at least according to the initial government reports, the rise in morale was hugely important, and a recognition that Pintupi were on the way to making their own decisions was highly lauded and defended. At the same time, and as government officials changed and the much loved 'Minister Bryant' was replaced with the more pragmatic Cavanagh as Minister of Aboriginal Affairs, accountability began to be expected of the local council and its plans. Officials asked what projects were they actually going to do in order to have wages? What economy would they propose for the future of living at Yayayi? As a 'self-determining community', they now had some responsibility to set a plan - and when I met (as interpreter) with Yayayi leaders and Cavanagh, I saw how disconcerted they were when he asked them exactly what they were going to do if they were allowed to run cattle on their land or muster horses.

Here, then, I want to add the perspective offered by Jeffrey Stead, community adviser to Yayayi in 1974:

One of the things I always remember about Yayayi was how it taught me something about community development. Like essentially it is a failure ...

Remember ... when there was ... football and we used to cart them around on the back of that trailer, take them to all the football matches ... You know, I'd been trained at ASOPA [Australian School of Pacific Administration], 'you got to do something that people were interested in.' So we graded that football oval, and we put the fence up so we knocked all those desert oaks down, we put a fence up? Then, the first cold day, remember? They knocked all the fence down and burned the fence for firewood. I said to myself, 'you have to learn a lesson here, Jeff.' [Hearty laugh] ... Firewood is much more important than football, that's for sure. (Interview with Jeff Stead, Melbourne, 7 June 2011) 
Perhaps one can summarise here to draw things together in considering these different perspectives. What horizons do they-and I-bring to these judgments? I have already mentioned the disappointments of Ian Dunlop and Terry Parry, which I would characterise as failures to live up to the romantic image, as a fall from a purer past.

Reflecting on his time as community adviser, Jeff Stead also had doubts about the success of Yayayi, which were related to the scale of violence there and the inabilities he experienced to do more than simply provision the place. However, his views - now of a lifelong experience with Aboriginal communities - were more nuanced. He remembered, for example, that the level of violence was particularly high during the time of Ian's filming: 'six weeks in when everyone was on the grog.' And he remembered the Yayayi Council meeting at that time trying to establish rules about grog-'but ... '. At this point, he shrugged, implying 'nothing'. His experience included inadequate support from the DAA in town. But he recognised that probably too much was expected of the council and the community's capacity for self-determination. Yayayi, as far as he remembers, was barely able to keep going.

Stead's point of view is very instructive - both in highlighting the failure of these unrealistic development projects that were the price, so to speak, of continued funding and in the lessons he learned. People may have different values and needs than are supposed in the plans for self-determination. Their actual needs may be so great that the capacity for development is undercut. Were the plans or expectations of self-determination unrealistic? Were they met?

I want to conclude by turning to the interview undertaken with Ken and Lesley Hansen, linguists from SIL who spent many, many years with the Pintupiin Papunya and almost all of their various community formations in outstations, dating from the late 1960s. ${ }^{21}$ The Hansens had been living and working with Pintupi people since 1965 and 1966, beginning at Papunya and following them to various community locations. This perspective has provided them particular insight, a sense of Yayayi as a juncture in Pintupi history. They described, in the interview, a range of dramatic changes in Aboriginal policy that were occurring at the time. What happened at Yayayi in 1973 and 1974 was, for them, based on the election of the Whitlam Labor Government, with its policy of 'self-determination', and the more or less concomitant 'outstation movement'. These changes were reversals of the much disliked assimilation program associated with Harry Giese's former administration of the Welfare Branch in the Northern Territory. Giese, Lesley Hansen remembered, 'was full-on social engineering, for assimilation'. As Ken elaborated, '[t]hat involved putting everybody

21 This interview was done by grant partners Peter Thorley and Pip Deveson, at the Hansens' home in New South Wales. 
together in large communities, forget all your backgrounds, everybody is all the same'. This had not served Aboriginal people well at Papunya-a view clearly articulated by C. D. Rowley's (1970, 1971a, 1971b) three-volume study of Aboriginal policy and its criticism of Aboriginal settlements as debilitating total institutions that robbed residents of their initiative and agency.

Lesley offered a moving example of the assimilation policy in action, a story that she told me when we all lived at Yayayi in 1973. This example involved a woman I knew as Murmuya, a recent migrant from the bush (in 1963), the wife of my close friend Freddy West Tjakamarra and mother of Bobby West, one of our consultants on this project. According to Lesley, the Welfare Branch officials were:

Insisting on the feeding of babies from six weeks on solids (which now nobody would do), and she [Murmuya] was angry. She'd say, 'I know how to look after my babies.' And she boycotted and wouldn't take her children there, so they slashed her meals. She couldn't get meals from the kitchen. You know, there was all that sort of thing going on. (Lesley Hansen, interview, 2012)

When they went out to Yayayi, moving along with the Pintupi, Lesley continued, 'with this new thing, they had control over what they ate, they had control over where they were living and how they were living'. Ken's conclusion to this part of the discussion is a precise articulation of what 'self-determination' meant then:

They could organise their own living patterns rather than being put into one of the Giese houses that were in line. They could organise their own cultural way of having relatives close that they interacted with and other people would have other areas. So, it gave them an opportunity to do things more their way. (Ken Hansen, interview, 2012)

Indeed, Ken's interpretation of what many regarded as the 'motorcar problem' is especially illuminating. As I have already said, with the move to Yayayi, shortly after, the government organised for the community to buy two trucks. Each was under the charge of a different local leader. Ken remembers that they would get petrol from Papunya and go out west from Yayayi, further away from human settlement, hunting with those trucks and a whole lot of men, and bring back meat. While this was certainly not the Government's aim, as Hansen notes, '[t]hat was another stage where people were learning to run their own things'. 'These were the first two vehicles that Pintupi people had in that area', and 'even at Papunya most of the vehicles were government-controlled and Aboriginal people were not able to use them, on the whole. But the two trucks were a landmark' (Ken Hansen, interview, 2012). 
The Hansens, among the very few people who could speak to Pintupi people in their own language, had seen the morbidity and misery of Pintupi in Papunya. They judged the Yayayi experience both from that perspective and based on their continuing intensive conversations with Pintupi. I believe that they, like me, identified with the local values and trajectories expressed by Pintupi people - and especially articulated a view expressed in Lovegrove's articulation of 'self-determination' - namely, that administration should 'be governed to a large extent by the expressed wishes of the people themselves and will not impress upon them those values through which we as Europeans judge to be important to a quality of life'.$^{22}$ Living in tents and/or bough shelters, having neither toilets nor ablution blocks, having no refrigeration or food storage, no doctors or nurses living there - these were not as important as having the basic ability to organise their own affairs.

It is not that Pintupi did not want these amenities of Anglo-Australian society; rather, their value paled before the possibility of independent living, freedom from the constraints of the large and competing groups at Papunya and the pressures of white administration. Was this not 'self-determination'? But was it a 'self-determination' with which administrators or government officials or anthropologists could live?

As a final note, or perhaps simply a postscript to this discussion, one must mention the early development of the successful cooperative Papunya Tula Artists at Yayayi. In the archival footage, the presence of this activity is illustrated by the filmed visit of Bob Edwards, head of the Aboriginal Arts Board (AAB), to Yayayi in June 1974. The existence of the AAB is an expression of the very same governmental direction envisioned in 'self-determination' by Nugget Coombs and the Office of Aboriginal Affairs, but here in the form of support for Indigenous art-making as cultural maintenance-a value on Aboriginal culture itself. If Yayayi has become only a memory, if a recorded one, of Pintupi assertion of their own direction, Papunya Tula Artists has continued into the present as a link to that past.

\footnotetext{
22 Lovegrove wrote about the connection between self-determination, initiative and confidence as fundamental to the move to Yayayi: 'The decision by this community in what it sees as its best interests, whilst causing some anxieties to this and other government departments as well as other interested and well meaning people is applauded as a display of initiative which it is hoped and expected will help to re-establish more self-reliance and self confidence in the group and it is recommended that this department respond with funds and resources to those requests put forward by the community which will enable their decision to be sustained.' NAA: F1, 1973/6202 Pintupi Outstation Yai Yaia, p. 149.
} 


\section{Conclusion}

I began this chapter with an expression of my sense of both nostalgia and ambivalence about the Pintupi project of self-determination at Yayayi. It is clear that there are bases for both sensibilities in the history of the outstation. But it is interesting that Pintupi who talk about the Yayayi period, through the film, do not regard it as the failure or dysfunction that some of the outside participants have.

I tried to engage with this bifurcation previously, in the second of two connected essays I published in the journal previously known as Mankind. In that article, pointedly titled 'A broken code: Pintupi political theory and contemporary social life' (Myers 1980), I argued that Pintupi at Yayayi did not really come to experience their unfortunate destruction of trucks (through lack of control in their use) as enough of a problem to force them to change their use (for hunting, and so on). On the one hand, they had their own theory, as I showed, that the Government owed them 'help' (as Neville Perkins maintained and as they also believed because the Government was their 'boss'). On the other hand, the Government could not - I came to realise - refuse to provide that help, which would have caused them to suffer unacceptably. In this way, I concluded at the time that the Pintupi people I knew had a better understanding of their world than I did, reflecting that I was imposing my own moralistic models of proper behaviour, in which self-determination means that you take care of your own affairs completely and also that a truck given for food transport should not be used for other purposes. Over time, I have also understood that Pintupi and perhaps more widely Indigenous models of personhood and sociality dictate a different hierarchy of responsibility. Some models of self-determination seem to require a particular response to modernity, a particular mode of selfhood and moral boundaries of the self. This is not necessarily a form of selfhood that Pintupi have embraced, at least not in the short time we have witnessed. Rather, what has prevailed is the form of sociality I sketched in the first article I published (Myers 1979) and which is evident in everyday life at Yayayi.

So what, then, of the model of difficult experiences and personal suffering motivating a change in cultural practice and values, in accord with local histories, as a path of self-determination? The history of the outstation at Yayayi is one of these histories, of course. But as I trace the path, leading eventually to Kintore and Kiwirrkura and the restoration of life in Pintupi homelands, it is far more complicated and bureaucratically involute than I would have anticipated. The withdrawal of the DAA, with its trained officers with knowledge of local communities and reach into support services, was, I would argue, a step too far. This left local communities such as Yayayi in charge of basic services such as water, mechanical help, medical services and, later, power. As self-determination, 
this exceeded the expectation of Pintupi people, who wanted to determine who came to do these services, but not necessarily to take them over completely. Later struggles in Papunya over housing and power, as services were switched from the Federal Government to Territory supervision, display what seems to be an almost constant change in sources of support, systems of support, personnel and regulations. What small community, with limited literacy, could easily surmount these obstacles?

Who is to say, then, that the outstation experiment has been or is a failure or a success? Indeed, from what point of view are we to take such a view? What sort of discourse permits one to stand outside the local cultural life and impose judgments of failure or success? When would or should this occur?

\section{Postscript}

Yayayi ended gradually in the period after 1976. It had slowly eroded in population from the initial high point of 300 people, as interpersonal conflicts and new opportunities led people to move to other communities - and also to establish other 'outstation' communities in the Papunya area. When I returned to Yayayi for a visit in the winter of 1979, only one extended family was still living there, under the leadership of Ronnie Tjampitjinpa. His elderly father and mother, his sister Yuyuya and her children, and his brother Kantjatjarra Tjampitjinpa and his family lived there together in a closely cooperating group. Ronnie remained, he told me, to hold custodianship of the storehouse of sacred objects the men had established at Yayayi. Other relatives from Yayayi had relocated some $30 \mathrm{~km}$ further west to the new community of Yinyalinkgi, where a bore had been drilled. This community incorporated a number of older Pintupi men: Shorty Lungkarta, Uta Uta Tjangala, Charley Tarawa and Ginger Tjakamarra, with his brother-in-law Hilary Tjapaltjarri. This move was made possible by the provision of more vehicles and water sources, and, as I argued in my monograph (Myers 1986), a devolution in size as Pintupi groups began to approximate smaller collections of kin groups who shared resources among themselves and had fewer conflicts of leadership. At the same time, deathsincluding a murder - strained the relationships among people who had been living together, leading to relocations and reorganisations of community life. Other communities were being established in the area, outposts from Papunya and Haasts Bluff, and teachers were travelling to visit and teach at these communities from the resource centre of Papunya. Their finances were, at this time, managed under the rubric of an 'outstation centre' at Papunya, but control over these resources and their allocations proved to be an issue of conflict until Pintupi from these outstations officially separated themselves from Papunya in moving further west to their own country at Kintore in 1981. These movements 
themselves were expressive of greater mobility through control of vehicles and the attempt of many people to re-establish relationships with long-separated relatives at Balgo Hills Mission (in the north) and then Tjulyurunya and Warakurna in the south. That is, these movements rehearsed former patterns of kinship connection and visiting in the context of self-determination.

To understand these changes, and the devolution of Yayayi, one does not need to posit a failure of self-determination. In fact, the pursuit of smaller communities and eventually the establishment of Kintore should be understood as exercises in the quest for some kind of autonomy and self-direction. For Pintupi people as I have known them, these movements are unexceptional, temporary accommodations to personal circumstances and ongoing political projects. What might have appeared as failure to those imagining sedentary communities of permanent residence was an assimilation of changing circumstances and options to Pintupi political projects.

\section{References}

Bryson, I. 2002. Bringing to Light: A History of Ethnographic Filmmaking at the Australian Institute of Aboriginal and Torres Strait Islander Studies. Canberra: Aboriginal Studies Press.

Howson, P. 2000. Reality and fantasy: The abject failure of Aboriginal policy. Quadrant 44(4): 20-4.

Hughes, H. 2007. Lands of Shame: Aboriginal and Torres Strait Islander 'Homelands' in Transition. Sydney: Centre for Independent Studies.

Johns, G. 2001. Waking up to Dreamtime: The Illusion of Aboriginal SelfDetermination. Singapore: Media Masters.

Myers, F. 1979. Emotions and the self: A theory of personhood and political order among the Pintupi. Ethos 7: 343-70.

Myers, F. 1980. A broken code: Pintupi political theory and contemporary social life. Mankind 12: 311-26.

Myers, F. 1985. Illusion and reality: Aboriginal self determination in Central Australia. In C. Schrire and R. Gordon (eds), The Future of Former Foragers. Cambridge: Cultural Survival, pp. 109-21.

Myers, F. 1986. Pintupi Country, Pintupi Self: Sentiment, Place and Politics among Western Desert Aborigines. Canberra \& Washington, DC: Australian Institute of Aboriginal Studies \& Smithsonian Institution Press. 
Myers, F. 1988. Burning the truck and holding the country: Property, time and the negotiation of identity among Pintupi Aborigines. In T. Ingold, D. Riches and J. Woodburn (eds), Hunter-Gatherers. Volume II: Property, Power and Ideology. Oxford: Berg, pp. 52-74.

Myers, F. 2006. We are not alone: Anthropology in a world of others. Ethnos 71(2): 233-64.

Rowley, C. D. 1970. The Destruction of Aboriginal Society: Aboriginal Policy and Practice. Volume 1. Canberra: The Australian National University Press.

Rowley, C. D. 1971a. Outcasts in White Australia: Aboriginal Policy and Practice. Volume 2. Canberra: The Australian National University Press.

Rowley, C. D. 1971b. The Remote Aborigines: Aboriginal Policy and Practice. Volume 3. Canberra: The Australian National University Press.

Spencer, B. and Gillen, F. 1899. The Native Tribes of Central Australia. London: Macmillan.

Sutton, P. 2001. The politics of suffering: Indigenous policy in Australia since the 1970s. Anthropological Forum 11(2): 125-73.

Sutton, P. 2009. The Politics of Suffering: Indigenous Australia and the End of the Liberal Consensus. Melbourne: Melbourne University Press.

Tindale, N. 1974. Aboriginal Tribes of Australia. Berkeley: University of California Press. 
This text is taken from Experiments in self-determination: Histories of the outstation movement in Australia, edited by Nicolas Peterson and Fred Myers, published 2016 by ANU Press, The Australian National University, Canberra, Australia. 